\title{
Penile rehabilitation following treatment for prostate cancer: an analysis of the current state of the art
}

\author{
Tariq Al Shaiji, MD ChB; Trustin Domes, MD; Gerald Brock, MD
}

See related article on page 49

\begin{abstract}
Despite recent advances in surgical technique using laparoscopic and robotic approaches for the management of early organconfined prostate cancer, most contemporary reports demonstrate significant rates of erectile dysfunction comparable to standard open approaches. Controversy remains related to many of the preand postoperative management strategies, including agents to enhance nerve recovery, erectogenic drugs, antioxidants, vasoactive injectables, vacuum erection devices and nerve grafting procedures. Additionally, the optimal timing of these interventions and their duration, dose, frequency and outcome thresholds remain ill-defined. In our paper, we provide a comprehensive literature review involving both the basic and clinical data surrounding rehabilitative approaches.
\end{abstract}

Can Urol Assoc J 2009;3(1):37-48

\section{Résumé}

Malgré des avancées récentes dans les techniques chirurgicales utilisant la laparoscopie et la robotique pour la prise en charge du cancer de la prostate au stade précoce, la majorité des rapports récents font état de taux significatifs de dysfonction érectile se comparant aux taux associés aux approches ouvertes standard. Bon nombre des stratégies de traitement préopératoires et postopératoires, comme les agents favorisant la récupération nerveuse, les médicaments érectogènes, les antioxydants, les agents vasoactifs injectables, les pompes péniennes et les greffes de nerfs, font toujours l'objet de controverses. Par ailleurs, le moment optimal pour effectuer ces interventions, la durée de ces dernières, la dose, la fréquence et le seuil d'évaluation des résultats demeurent encore bien mal définis. Cet article de synthèse présente une revue approfondie de la littérature comprenant les données de recherche fondamentale et les données cliniques concernant les approches de réadaptation.

\section{Introduction}

Prostate cancer is the second most common malignancy affecting the adult male population, after skin cancer. ${ }^{1,2}$ Radical prostatectomy (RP) is a well-established treatment option for organ-confined prostate cancer. ${ }^{3}$ In the current era of early detection, many young and sexually active men are under- going surgery and are thus expressing concern about preservation of erectile function after the procedure, a fact that is true for older men as well. Since Walsh and Donker ${ }^{4}$ published their landmark article describing the etiology and prevention of impotence following retropubic RP in 1982, the nerve-sparing technique they described is widely employed and believed to improve postoperative erectile function. ${ }^{5}$ Furthermore, there continue to be modifications to the nervesparing technique in an attempt to minimize nerve compromise and improve postoperative potency, as reported by Chuang and coauthors ${ }^{6}$ and Masterson and colleagues. ${ }^{7}$ However, optimal sexual functioning often requires 18 to 42 months to return, even among men in whom bilateral nerve sparing was performed, with reported recovery rates varying from $16 \%$ to $86 \% .^{8,9}$ Sexual dysfunction has been reported to be an independent determinant of a poorer general health-related quality of life at 2 years after primary treatment for prostate cancer. ${ }^{10}$ Recent advances in the understanding of the pathophysiology of postprostatectomy erectile dysfunction (PED) have stimulated great attention directed toward the concept of penile rehabilitation, in which prophylactic measures are instituted to promote early recovery of sexual and erectile function as well as to modify postprostatectomy pathophysiological changes. In our review, we discuss the pathophysiology of PED as well as the rationale for and current data regarding penile rehabilitation, based on an extensive search of the peer-reviewed English-language scientific literature from 1960 to 2008.

\section{Pathophysiology of postprostatectomy erectile dysfunction}

The etiology of erectile dysfunction (ED) following surgery for prostate cancer is likely multifactorial. ${ }^{11}$ The predictors for recovery of erectile function following nerve-sparing radical prostatectomy (NSRP) depends on patient factors, cancer factors, surgical techniques and preoperative degree of erectile function, which are summarized in Table 1. Men who report some degree of ED or use phosphodiesterase type 5 (PDE5) inhibitors before surgery are more likely to 
develop severe postoperative ED. ${ }^{12}$ A study by Raina and colleagues ${ }^{13}$ showed that good preoperative erectile function was associated with superior erectile function outcomes after NSRP.

Patients undergoing NSRP often experience impairment of erections in the early postoperative period. This has been related to the development of reversible nerve injury (neurapraxia), which is believed to be caused by mechanically induced nerve stretching that may occur during prostate retraction, thermal damage to nerve tissue caused by electrocautery, ischemia of the nerves secondary to disruption of blood supply while attempting to control surgical bleeding, and local inflammatory effects associated with surgical trauma, even in the hands of most experienced surgeons. ${ }^{14,15}$

The mechanism of cavernous nerve fibre injury involves, in part, wallerian degeneration resulting in loss of normal nerve tissue connections to the corpora cavernosa and associated neuroregulatory functions. Both of these processes cause degeneration and atrophy of the cavernosal smooth muscle and tunica albuginea. ${ }^{16,17}$ Oxygenation of the cavernous tissue is an important factor in the regulation of local mechanisms of erection through modulation of nitric oxide (NO) synthesis, the primary neurotransmitter of

\begin{tabular}{|c|c|c|c|}
\hline Factors & Parameters & Advantage & Disadvantage \\
\hline \multirow[t]{5}{*}{ Patient } & Age & $\leq 65 \mathrm{yr}$ & $>65 \mathrm{yr}$ \\
\hline & Comorbidities & Absence & Presence \\
\hline & $\begin{array}{l}\text { Household } \\
\text { income }\end{array}$ & High & Low \\
\hline & Counseling & Yes & No \\
\hline & $\begin{array}{c}\text { Penile } \\
\text { rehabilitation }\end{array}$ & Early & Late/none \\
\hline \multirow[t]{3}{*}{ Cancer } & Stage & $\leq \mathrm{T} 2$ & $\geq \mathrm{T} 3$ \\
\hline & Grade & Low & High \\
\hline & Localization & $\begin{array}{l}\text { Organ- } \\
\text { confined }\end{array}$ & Advanced \\
\hline \multirow[t]{2}{*}{ Surgery } & $\begin{array}{l}\text { Nerve-sparing } \\
\text { status }\end{array}$ & Bilateral & Unilateral/none \\
\hline & $\begin{array}{l}\text { Interval from } \\
\text { surgery }\end{array}$ & $>12 \mathrm{mo}$ & $<12 \mathrm{mo}$ \\
\hline $\begin{array}{l}\text { Preoperative } \\
\text { erectile } \\
\text { function }\end{array}$ & SHIM score & $\geq 15$ & $<15$ \\
\hline
\end{tabular}

erection. When this is impaired or is abolished by permanent nerve injury or neurapraxia, loss of cavernous smooth muscle results. ${ }^{5}$ It has been shown that cavernous nerve injury in animal models results in a reduction in nitric oxide synthase (NOS) staining. ${ }^{18}$ Nocturnal penile tumescence that occurs during the rapid eye movement sleep phase in men with normal erections has been identified as an important component in preserving normal erectile function through tissue oxygenation, a phenomenon which is lost during the period of neurapraxia. ${ }^{19-21}$ The chronic low oxygen tensions within the postoperative penis are believed to initiate severe fibrotic changes in the cavernosal tissue, which ultimately lead to venoocclusive dysfunction..$^{22}$

A penile hemodynamic study among patients who underwent NSRP who had no pharmacological support in the initial year after surgery revealed a progressive incidence of venous leakage, varying from $14 \%$ at 4 months to $50 \%$ at later than 12 months. ${ }^{23} \mathrm{~A}$ reduction in arterial inflow has also been reported by several authors, associated with the ligation of accessory internal pudendal arteries during prostatectomy..$^{24}$ In a small series in 1996, Mulhall and Graydon ${ }^{24}$ reported that arterial insufficiency is seen in almost all patients with ED after RP; however, in a subsequent publication evaluating a larger study population, Mulhall and colleagues ${ }^{23}$ noted arterial insufficiency in $56 \%$ of the group studied. The combination of nerve damage with decreased arterial inflow may intensify hypoxia and ultimately lead to apoptosis or programmed cell death, which has recently been linked to the pathophysiology of PED by increasing the deposition of connective (scar) tissue. ${ }^{11,25}$ In a rat model, User and colleagues ${ }^{17}$ found that apoptotic cells were smooth muscle cells and not endothelial cells, with cell death noted to peak at 2 days after bilateral neurectomy, suggesting early smooth muscle cell dysfunction as a mechanism for the previously observed veno-occlusive dysfunction. ${ }^{26} \mathrm{McVary}^{27}$ has shown that both intrinsic and extrinsic apoptotic pathways were activated in rats whose cavernous nerves were disrupted.

The postprostatectomy penis changes in several important ways: it is often more fibrotic, it is frequently smaller and it lacks erectile capacity. Penile hypoxia has been linked to increased production of transforming growth factor- $\beta$ (TGF- $\beta 1$ ), which is implicated in collagen disposition, as 
shown by Moreland and colleagues. ${ }^{28}$ They demonstrated a 2.5 - to 4.5 -fold increase in collagen synthesis in cultured cavernosal smooth muscle cells in response to TGF- $\beta 1$. Furthermore, the authors demonstrated a 2 - to 3 -fold increase in TGF- $\beta 1$ expression in cells subjected to low oxygen tension $\left(\mathrm{PO}_{2}\right.$ of $\left.30 \mathrm{~mm} \mathrm{Hg}\right)$. In addition, they showed that the addition of prostaglandin E1 (PGE1) suppressed the effect of TGF- $\beta 1$ on collagen synthesis. In a rabbit model, Daley and colleagues ${ }^{29}$ reported that the production of PGE1 in the cavernosal muscle, which suppresses the TGF- $\beta 1$-induced collagen accumulation, was also oxygen dependent. Exposure to a low oxygen tension environment and increased expression of TGF- $\beta 1$ activates a molecular cascade resulting in increased collagen and other connective tissue synthesis. In contrast, exposure to high oxygen tension leads to increased expression of PGE1 and activates an alternate cascade to decrease collagen synthesis..$^{30}$ In an experimental model, significant overexpression of collagen type I and III was found in rats that had undergone bilateral excision of the cavernosal nerves, compared with controls. ${ }^{31}$ Once the trabecular smooth muscle is replaced with collagen, this leads to muscle fibrosis, loss of the veno-occlusive mechanism and an inability to maintain intrapenile pressure. ${ }^{32}$

Shortening of the penis is often reported among patients who have undergone RP. Mulhall proposed a categorization of penile length changes into early and reversible postoperative penile contractions (as a consequence of the so-called sympathetic overdrive) and delayed, permanent structural alterations (owing to denervation apoptosis and cavernous hypoxia-induced collagenation). ${ }^{33}$ Penile shortening peaks at the time of catheter removal and it continues to a lesser but significant degree for at least 1 year. ${ }^{34}$

\section{Rationale for penile rehabilitation}

The concept of penile rehabilitation is founded on 3 concepts: 1) improving cavernosal oxygenation, 2) promoting endothelial protection and 3) preventing cavernosal nerve injury-induced structural changes. ${ }^{9}$ Early interventions to prevent penile hypoxia, cavernosal fibrosis and its long-term complications are gaining increasing interest and enthusiasm. Several studies have been reported evaluating the effectiveness of artificially induced erection after surgery to prevent permanent damage.

The first study to demonstrate an advantage of early return of erections was reported by Montorsi and colleagues ${ }^{35}$ in a 1997 randomized controlled trial among patients who underwent bilateral NSRP. The authors showed that recovery of spontaneous erections occurred at 6 months in 8 of 12 patients who self-injected with prostaglandin-E, versus 3 of 15 who did not receive injections. The study was not placebo-controlled and had a small number of participants. Since then, several prospective studies have been performed with a number of modalities either alone or in combination, including, but not limited to, PGE1 injection or medicated urethral system for erection (MUSE), vacuum devices and PDE5 inhibitors. The data supporting pharmacological penile rehabilitation involve both animal models and human volunteers. Potential early treatment options are summarized in Table 2.

\section{Smooth muscle preservation}

Since Goldstein and colleagues ${ }^{36}$ first reported the role of the cavernosal smooth muscle in the normal erection in 1982, several investigators demonstrated that normal smooth muscle content and function are essential in the initiation and maintenance of erection. The integrity and function of any smooth muscle is dependent on tissue oxygenation.

lacono and colleague ${ }^{37}$ evaluated histomorphological alterations in cavernous smooth muscle and collagen content after RP. Penile biopsy was performed before and after RP (2 mo and $12 \mathrm{mo}$ ) in humans. Compared with preoperative biopsies, postoperative biopsies showed a significant decrease in elastic fibres and smooth muscle content and a significant increase in collagen content. Nehra and colleagues $^{38}$ examined cavernosal histology in an animal model. They demonstrated that the lower the smooth muscle content among penile biopsies, the higher the flow-to-maintain values during cavernosometry, supporting the concept of erectile tissue damage-induced venous leak.

Emerging data support the concept that the longer the patient waits after surgery before initiating erectile function, the greater the likelihood for development of venous leak, implying underlying corporal smooth muscle fibrosis. ${ }^{9}$ This finding was supported by Mulhall and coworkers ${ }^{23}$ who 
Al Shaiji et al.

showed that time postoperatively was significantly associated with the incidence of venous leakage ( $14 \%$ at $<4$ mo and $35 \%$ at $9-12 \mathrm{mo})$. In addition, they demonstrated that the prognosis for the return of functional erection is worst when venous leakage is present.

\section{Intracavernous injections of vasoactive agents}

Prostaglandin E1 induces erections by directly stimulating the production of cyclic adenosine monophosphate (cAMP) within the smooth muscles cells ${ }^{39}$ and thus does not require a function- ing nerve to induce smooth muscle relaxation. ${ }^{21}$ Brock and coauthors ${ }^{40}$ demonstrated that longterm intracavernosal self-injection (ICSI) of alprostadil improved penile circulation and led to a return of spontaneous erection in men with arteriogenic ED, thus confirming a potential curative role of this therapeutic modality in selected patients. Dennis and McDougal ${ }^{41}$ reported that a combination of papaverine and phentolamine was $85 \%$ effective in producing erections in a small series of 14 patients who had undergone RP. Following the pioneering work of Montorsi and coworkers, ${ }^{14}$ groups worldwide have used

\begin{tabular}{|c|c|c|}
\hline Modality & Advantages & Disadvantages \\
\hline PDE5 inhibitors & $\begin{array}{l}\text { Well tolerated } \\
\text { Ease of use } \\
\text { Improved nocturnal erections } \\
\text { Endothelial-protection effects and preservation } \\
\text { of smooth muscle after cavernous nerve injury } \\
\text { Induces of cavernosal oxygenation in the } \\
\text { absence of erection } \\
\text { May augment the usage of ICSI } \\
\text { May lower the incidence of myocardial } \\
\text { infarction } \\
\text { Increased pulmonary artery oxygenation }\end{array}$ & $\begin{array}{l}\text { High cost } \\
\text { Most studies are animal models } \\
\text { Requires the presence of a functional nerve }\end{array}$ \\
\hline $\begin{array}{l}\text { Intracavernous injections of } \\
\text { vasoactive agents }\end{array}$ & $\begin{array}{l}\text { Compunded agents may have a lower cost } \\
\text { compared to PDE5 inhibitors } \\
\text { Does not require a functioning nerve to induce } \\
\text { smooth muscle relaxation } \\
\text { Potentiate the response of PDE5 inhibitors }\end{array}$ & $\begin{array}{l}\text { Poor compliance } \\
\text { High dropout rates } \\
\text { Injection pain } \\
\text { Patient difficulty in reproducing a successful } \\
\text { injection } \\
\text { Injection- and agent-induced penile fibrosis } \\
\text { Needle phobia } \\
\text { Painful erection } \\
\text { Invasiveness }\end{array}$ \\
\hline Intraurethral alprostadil & $\begin{array}{l}\text { Improves the response to oral agents } \\
\text { Does not require a functioning nerve to induce } \\
\text { smooth muscle relaxation }\end{array}$ & $\begin{array}{l}\text { Urethral irritation } \\
\text { Pain } \\
\text { Application difficulties } \\
\text { High cost } \\
\text { Low response rate } \\
\text { Inconsistent efficacy }\end{array}$ \\
\hline Vacuum constriction device & $\begin{array}{l}\text { One-time cost } \\
\text { Ease of use } \\
\text { Ensure multiple erections on a daily basis }\end{array}$ & $\begin{array}{l}\text { Poor compliance } \\
\text { Unproven mechanism in improving } \\
\text { spontaneous erection }\end{array}$ \\
\hline Combination & $\begin{array}{l}\text { Synergistic effect } \\
\text { Targets different pathways within the erectile } \\
\text { bodies } \\
\text { Enhances erectile rigidity }\end{array}$ & $\begin{array}{l}\text { Poor compliance } \\
\text { Increased side effects profile } \\
\text { Negative synergistic effects on the } \\
\text { cardiovascular and gastrointestinal tracts }\end{array}$ \\
\hline
\end{tabular}


early PGE1 injections extensively as it is effective for most postprostatectomy patients, regardless of the status of their cavernosal nerves. However, the lack of patient compliance secondary to penile pain remains a major obstacle to its widespread adoption by patients. ${ }^{42}$ In general, patients using intracavernosal injections switch to oral therapy or otherwise discontinue injections because injections are cumbersome and inconvenient..$^{43}$ In addition to penile pain, other reported side effects include subcutaneous hemorrhage, penile nodules or fibrosis, corporal plaque formation and prolonged erection. ${ }^{44,45}$

Mulhall and coauthors ${ }^{46}$ followed up 132 patients in a prospective nonrandomized fashion after the patients were placed in "rehabilitation" or "no rehabilitation" groups following RP. Patients undergoing rehabilitation agreed to take sildenafil or intracavernosal alprostadil to induce erection 3 times weekly starting within the first 4 weeks after surgery. After 18 months of followup, $52 \%$ of the men in the rehabilitation protocol group reported spontaneous functional erections, compared with $19 \%$ of the men in the "no rehabilitation" group. Furthermore, a significantly greater number of men in the rehabilitation group responded to sildenafil treatment after the 18month period with an erection sufficient for intercourse $(64 \%$ v. $24 \%)$.

In another study, Gontero and colleagues ${ }^{47}$ investigated alprostadil injections at various time points after non-nerve-sparing radical prostatectomy (NNSRP). They found that $70 \%$ of patients receiving injections within the first 3 months after NNSRP were able to achieve erections sufficient for intercourse, compared with $40 \%$ of patients receiving injections after the first 3 months. However, because all men received only a single injection treatment, it is unclear whether men who responded in the early group would continue to respond after 12 months.

Nandipati and colleagues ${ }^{48}$ showed in a small non-placebo-controlled series of 22 men initiated on intracavernosal treatment 2-3 times a week and on immediate nightly sildenafil $50 \mathrm{mg}$, at a mean follow-up of 6 months (3-8 mo), 50\% of men reported weak spontaneous erections, though none were sufficient for intercourse. Ninety-six percent of the men were sexually active with injection therapy or a combination. A weakness of the study was its short-term follow-up and lack of a randomized nontreatment control arm. The authors identified that a potential psychological benefit of treatment is early resumption of sexual activity.

With 4-year follow-up of 102 patients enrolled in an ICSI program following RP, Raina and coauthors ${ }^{43}$ found that $68 \%$ of patients achieved erections sufficient for sexual intercourse with a compliance to IC injections of $70.6 \%$. The regimens used in this study were PGE1 alone, high-dose triple therapy or low-dose triple therapy. The type of RP surgery (bilateral NS, unilateral NS and non-NS) and type of injection regimen did not affect the efficacy of this therapy. On the other hand, Bechara and coauthors ${ }^{49}$ performed a prospective study which showed that the 3-drug mixture is more effective than high-dose PGE1 alone in achieving erections suitable for penetration. In addition, Baniel and colleagues $^{50}$ found that ICSI of papaverine, phentolamine and PGE1 combination was effective in 51 (85\%) of 60 patients following RP using structured interviews with patients and their partners.

\section{Intraurethral prostaglandin}

Intraurethral prostaglandin is delivered as a suppository of alprostadil with MUSE. The ability of alprostadil to directly induce smooth muscle relaxation and increase the penile blood supply, even in the presence of local nerve trauma, in addition to stimulating regeneration of damaged nerves, suggests that this drug may be pivotal in rehabilitating damaged nerves and blood vessels. ${ }^{21}$ In 101 patients with ED, the administration of PGE1 intraurethrally resulted in a $37 \%-57 \%$ increase in corporal oxygen saturation despite marginal tumescence. ${ }^{51}$ Intraurethral prostaglandin is associated with urethral pain and discomfort, low response rate and inconsistent efficacy, but has an exceedingly low incidence of priapism. ${ }^{52,53}$ The discomfort experienced during administration is secondary to the prostaglandin's direct effect on pain receptors as reported by Lepor and McCullough. ${ }^{53}$ The authors suggest that the use of lidocaine in the urethra obviates this discomfort at the time of administration and that the pain that occurs, which is usually mild and tolerable, decreases with future treatments.

Costabile and coauthors ${ }^{54}$ performed a retrospective analysis of the MUSE clinical trial to evaluate the erectile response to alprostadil in 384 men with ED after RP. The study showed efficacy in 
Al Shaiji et al.

men after RP, regardless of the nerve status. The "in office" response rate was $70 \%$, with a $57 \%$ "home success" rate. The urethral burning, penile pain and lack of penile rigidity resulted in an overall satisfaction rate of about $20 \%$ in the author's practice after RP.

McCullough ${ }^{55}$ explored the possible mechanism of penile rehabilitation with intraurethral alprostadil. Among a subgroup of 22 men enrolled in a larger randomized comparative penile rehabilitation trial of nightly alprostadil versus sildenafil, preoperative corporal oximetry as well as corporal oximetry was performed before and after their first doses of MUSE (125 or $250 \mu \mathrm{g}$ ). The first dose of MUSE $(125 \mu \mathrm{g})$ was administered the day the catheter was removed ( $1 \mathrm{wk})$. After 1 month of using MUSE 125 nightly, the MUSE dose was increased to $250 \mu \mathrm{g}$. Corporal oximetry was done at 15 to 20 minutes after dosing. The author found that both the 125- and 250- $\mu$ g alprosdadil significantly improved corporal and glanular oxygen saturation despite lack of penile rigidity.

Raina and colleagues ${ }^{56}$ reported their experience at the Cleveland Clinic with early post-NSRP intraurethral alprostadil in a prospective nonrandomized study of 91 patients. Fifty-six men received early intraurethral alprostadil, and $35 \mathrm{did}$ not receive any early erectogenic treatment except for oral PDE5 inhibitors on an as-needed basis. Self-administration of MUSE was initiated about 3 weeks after RP. At a median follow-up of 6 months, $74 \%$ of the patients who remained on MUSE were able to regain erections sufficient for vaginal intercourse as opposed to $37 \%$ of the untreated control group. All 56 patients who received MUSE reported mild penile aching or urethral burning and, of these, $32 \%$ discontinued treatment.

\section{Vacuum constriction devices}

Vacuum constriction devices (VCDs) act by promoting engorgement of the penis through negative pressure effects on the corporeal chambers. When used with a venous constriction ring to maintain tumescence, there is documented evidence showing adequate erections. ${ }^{45}$ Lack of spontaneity, difficult mechanics and complications have led to high discontinuation rates. ${ }^{8}$ Tightness or pain from the constriction ring and diminished sensation of the phallus and glans are reported side effects. ${ }^{57}$ What remains to be proven, however, is the role of VCDs in rehabilitation, given the low oxygen tension of blood within the penis following their use.

Bosshardt and colleagues ${ }^{58}$ evaluated the origins of blood for VCD-induced erection. Blood gas analyses were obtained from the corpora cavernosa immediately after application of constriction ring. The measurements were repeated 15 and 30 minutes later with the constriction ring in place. The blood gas results of the corpora cavernosa were compared with the arterial blood from radial artery and venous blood from antecubital fossa. The result showed that mean oxygen saturation of corporeal blood immediately after VCD-induced erection was $79.2 \%$, compared with $94.5 \%$ from arteries and $54.7 \%$ from veins. The authors calculated that $58 \%$ of blood with VED-induced erection was arterial and $42 \%$ of blood was venous in origin. The $\mathrm{O} 2$ saturation decreased significantly after 30 minutes with the ring in place. These findings support the rationale for not applying the constrictive ring when VCD is used for penile rehabilitation. ${ }^{25}$

Köhler and coauthors ${ }^{59}$ recently performed a pilot study on the early use of the VCD after RP. Twenty-eight men undergoing RP were randomized to early intervention ( 1 mo after surgery, group 1) or a control group (6 mo after surgery, group 2) using a traditional VCD. Only patients in whom unilateral or bilateral nerves were spared were subsequently randomized. Patients in group 1 followed a daily rehabilitation protocol consisting of $10 \mathrm{~min} / \mathrm{d}$ using the VCD with no constriction ring, for 5 months. The International Index of Erectile Function (IIEF) scores were significantly higher in group 1 than group 2 at 3 and 6 months after surgery. Stretched penile length was significantly decreased at both 3 and 6 months, by about $2 \mathrm{~cm}$ in group 2. On the other hand, stretched penile length was preserved in group 1 at all sample times. The authors acknowledge that sample size limits the inferences that can be drawn from the statistical analyses. Another potential weakness of the study is the potential for interobserver variability in measuring penile length.

Raina and coworkers ${ }^{60}$ prospectively assessed the daily use of VCD starting within 2 months after surgery in 109 patients undergoing NSRP or NNSRP. The patients were randomized to VCD use daily for 9 months (group $1 ; n=74$ ) or observation without any erectogenic treatment (group 2; $n=35$ ). After 9 months of treatment, $17 \%$ of patients using the device had return of natural erec- 
tions sufficient for intercourse, compared with $11 \%$ of patients in the nontreatment group. Interestingly, $23 \%$ of patients in the treatment group reported a decrease in penile length and circumference, compared with $60 \%$ in the nontreatment group. Although the actual mechanism of action of the VCD remains to be elucidated, one possibility is that endothelial NOS is liberated from the shear stress, inducing smooth muscle relaxation in the absence of neural sources.

\section{Phosphodiesterase type 5 inhibitors}

Since their introduction to clinical medicine 10 years ago, PDE5 inhibitors have revolutionized the treatment of ED of all etiologies, including PED. The erectogenic mechanism of PDE5 inhibitors is well described. ${ }^{61}$ The cyclic guanosine monophosphate (cGMP) signaling pathway within the cavernosal smooth muscle cell is a key mechanism responsible for erection and PDE5 inhibitors work by augmenting this pathway. With sexual stimulation, the cavernous nerves and endothelial cells produce NO, which stimulates guanylyl cyclase and cGMP production in cavernosal smooth muscle cells. PDE5 normally degrades cGMP, but when inhibited by PDE5 inhibitors, increased cGMP acts as a second-messenger to activate a cGMP-specific protein kinase leading to downstream decrease intracellular calcium, smooth muscle relaxation and, ultimately, erection.

The potential rehabilitative effects of chronic PDE5 inhibitor use were first demonstrated in animal studies, using diabetic, Peyronie disease (PD) and cavernous nerve injury models. In a diabetic rat model, De Young and coauthors ${ }^{62}$ demonstrated improved endothelial and smooth muscle protein expression and penile histological morphology with chronic vardenafil use compared with controls. Similarly, Ahn and colleagues ${ }^{63}$ exposed diabetic rats to 8 weeks of PDE5 inhibitors and found preservation of penile smooth muscle and endothelial cells and decreased expression of TGF- $\beta 1$ and resultant penile fibrosis compared with control. Ferrini and colleagues ${ }^{64}$ have shown in a PD-like rat model, in either an "early preventative" (daily vardenafil starting the day after TGF- $\beta 1$ injection into the tunica albuginea) or "late therapeutic" (daily vardenafil after PD-like plaque was already formed) regimen, that chronic vardenafil reduced the collagen:smooth muscle ratio, myofibroblast content and TGF- $\beta 1$ expression, and increased the apoptotic index of fibroblast cells. They additionally demonstrated that the higher daily dose was more effective than the lower dose and the "early preventative" treatment approach was more effective at reducing plaque size than the "late therapeutic" regimen. In the cavernous nerve injury rat model, meant to simulate postprostatectomy nerve damage, similar findings with chronic PDE5 inhibitor use are observed. Bilateral cavernosal neurotomy in the rat leads to overexpression of TGF- $\beta 1$ and collagen $^{31}$ and to smooth muscle cell apoptosis. ${ }^{17}$ Multiple groups using this animal model have demonstrated reversal of these biochemical and histological findings with chronic PDE5 inhibitor use. Ferrini and colleagues ${ }^{65}$ have demonstrated increased inducible NOS, increased smooth muscle cell replication and normalization of dynamic infusion caverosometry with 45 days of vardenafil compared with controls in their rat bilateral cavernosal neurotomy model. Vignozzi and coworkers $^{66}$ and Kovanecz and colleagues ${ }^{67}$ have used similar models and have found that chronic tadalafil and sildenafil, respectively, have antifibrotic properties and a protective effect on cavernosal smooth muscle similar to vardenafil, indicating that the antifibrotic impact of PDE5 inhibitors likely represents a class effect.

Human studies have verified a number of the important findings discovered in the bilateral cavernosal neurotomy animal models. Mulhall and colleagues ${ }^{23}$ have shown that penile tissue histologically changes after RP with decreased elastic fibre and smooth muscle content and increased collagenation leading to a decrease in penile length and veno-occlusive dysfunction. Schwartz and coauthors ${ }^{68}$ conducted an important experiment that demonstrated that 6 months of sildenafil had the ability to halt (at $50 \mathrm{mg} / \mathrm{d}$ ) or reverse (at $100 \mathrm{mg} / 2 \mathrm{~d}$ ) the loss of cavernosal smooth muscle postprostatectomy by comparing penile biopsies pre- and postoperatively.

Although the clinical utility of on-demand PDE5 inhibitor use in PED is well established, the rehabilitative benefits of chronic PDE5 inhibitor postprostatectomy use continues to be explored. Even with meticulous nerve-sparing dissection, some degree of neurapraxia is unavoidable, as has been documented previously via Rigiscan (Plethora Solutions) demonstrating a complete loss of noc- 
Al Shaiji et al.

turnal tumescence 4 weeks after NSRP. ${ }^{69}$ It has been shown that nightly sildenafil significantly improves nocturnal erections after nerve-sparing prostatectomy, which is theorized to be critical in the penile rehabilitative process by preventing penile hypoxia and resulting fibrosis and veno-occlusive dysfunction. ${ }^{70,71}$ This was demonstrated by Montorsi and colleagues, ${ }^{70}$ who showed that in more than $70 \%$ of patients, the administration of sildenafil produced nocturnal erections that were significantly stronger than those after administration of a placebo. However, it should be emphasized that in this study a number of inclusion and exclusion criteria were followed, producing a selected study population and limiting its findings to a more general patient base.

Padma-Nathan and colleagues ${ }^{72}$ and PadmaNathan and coauthors ${ }^{73}$ have recently published the first randomized placebo-controlled multicentre trial assessing the clinical utility of chronic PDE5 inhibitor use. Seventy-six men were randomized into 3 arms 4 weeks after NSRP: 23 patients in the sildenafil $50 \mathrm{mg} / \mathrm{d}$ arm, 28 patients in the sildenafil $100 \mathrm{mg} / \mathrm{d}$ arm and 25 patients in the placebo arm. Patients took daily medication for 36 weeks and had an 8-week washout period. The primary outcome of the study was the ability to achieve a natural erection after the washout period without any medications. Twenty-seven percent of patients taking sildenafil (50 or $100 \mathrm{mg} / \mathrm{d}$ ) were able to achieve a natural erection, versus $4 \%$ in the placebo group. Although this was a 7-fold improvement, this study has been marginalized because of the low baseline erection rates in both groups 11 months after a nerve-sparing prostatectomy. Moreover, the study involved only 76 patients (51 men in the treatment group), suggesting the need for a larger trial. Other authors have concluded that although the baseline erection rates are poor, early postoperative chronic use of PDE5 inhibitors should significantly improve many surgeons baseline results. ${ }^{74}$

Despite early encouraging results, most studies addressing chronic PDE5 inhibitor use in the postprostatectomy population have not been ideal. These studies have recruited a relatively small number of patients, have been conducted only at single institutions with inherent bias, have been non-placebo-controlled and have not directly compared chronic PDE5 inhibitor with on-demand use. Two studies have recently been published to address the question of whether chronic PDE5 inhibitor use is superior to on-demand dosing. In the RESTORE study, Zumbe and colleagues ${ }^{75}$ designed a randomized, placebo-controlled, double-blind, multicentre study in a mixed population of patients with mild to moderate ED to directly compare once daily vardenafil $10 \mathrm{mg}$ plus ondemand placebo for $12(n=76)$ or 24 weeks $(n=79)$, or once daily placebo plus on-demand vardenafil $10 \mathrm{mg}$ for 24 weeks $(n=77)$. After the treatment phase of the study, all study groups were compared after a 4-week washout period with placebo. The primary outcome was change in IIEFEF score from baseline to end of the washout period, although analyses were conducted throughout different points in time during the study as well. There was no statistically significant difference in baseline-adjusted IIEF-EF scores between all 3 groups at any point in the study. Additionally, after cessation of treatment, erectile function decreased in all groups, indicating that chronic vardenafil treatment did not provide any prolonged advantage over on-demand administration. A limitation of this study was that the "real life" context of ondemand dosing could not be truly reflected, because all patients were administered either vardenafil or placebo on a daily basis, with a second tablet being taken on-demand.

A very recent landmark article by Montorsi and colleagues ${ }^{76}$ focused exclusively on patients who had undergone a NSRP. This large randomized, placebo-controlled, double-blind, multicentre study evaluated nightly versus on-demand vardenafil use in men with normal preoperative erectile function (IIEF-EF $\geq 26$ ) who had undergone a NSRP for low-risk prostate cancer. Within 14 days of surgery, men were randomized into 3 study arms: placebo $(n=210)$, vardenafil $10 \mathrm{mg}$ nightly with on-demand placebo $(n=210)$ and nightly placebo with on-demand vardenafil $10 \mathrm{mg}$ $(n=208)$. Treatment occurred over a 9-month period after which there was a single-blind placebo washout for 2 months and an additional 2 month open-label vardenafil on-demand period. The primary end point was percentage of patients with IIEF-EF score $\geq 22$ (defined as mild ED) after the 2 -month washout period, with secondary end points evaluating the same finding at the end of the double-blind treatment period and at the end of the open-label period. The SEP3 question "Did your erection last long enough for you to have suc- 
cessful intercourse?" was also assessed at each time point. After the double-blind treatment period, on-demand vardenafil was associated with significantly greater IIEF-EF scores $\geq 22$ compared with placebo $(p<0.001)$ and nightly vardenafil $(p=0.006)$. Additionally, the successful rates of the SEP3 question were statistically significant, in favour of on-demand vardenafil $(45.9 \%)$ compared with nightly vardenafil $(34.5 \% ; p=0.011)$ and placebo $(25 \% ; p<0.001)$. After the singleblind washout and open-label on-demand period, there were no statistically significant differences among the 3 treatment groups, indicating that chronic vardenafil use did not offer any additional clinical benefit.

Currently, the main absolute contraindication to the use of PDE5 inhibitor is the use of nitroglycerin or nitrate-containing compounds, that may lead to clinically significant hypotension and syncope. ${ }^{8}$ Reported side effects include headache, visual changes, dizziness, flushing, nasal congestion and dyspepsia. ${ }^{77-79}$ Furthermore, the cost to the patient has been an unavoidable issue. ${ }^{9}$

\section{Combination therapy}

The use of combination therapy regimens has been studied recently. The advantages include additive or synergistic effects that may be achieved by targeting 2 or more different erectile pathways within the erectile bodies optimizing erectile rigidity. An example is the combination of a PDE5 inhibitor with intraurethral alprostadil. This combination results in elevation of both cAMP (by the alprostadil) and cGMP (from the PDE5 inhibitor), which mediates smooth muscle relaxation via complementary pathways within penile erectile tissues. Phosphodiesterase type 5 inhibitors, such as sildenafil, act indirectly and require sexual stimulation and endogenous $\mathrm{NO}$ production to activate the cGMP pathway to be effective. In contrast, agents such as PGE1 act directly on the trabecular smooth muscle, binding to specific receptors and increasing CAMP synthesis. ${ }^{8}$ Another example of combination therapy is trimix. These combinations are based on the different mechanisms of action of these drugs. PGE1 activates CAMP, phentolamine inhibits the $\alpha$-adrenoceptors, and papaverine promotes the action of the generated cAMP/ cGMP by nonselectively inhibiting phosphodiesterases. ${ }^{80}$ However, a potential safety concern is that most of the erectogenic agents have smooth muscle relaxing properties which may promote synergistic effects on the cardiovascular and gastrointestinal tracts. ${ }^{45}$

Yassin and colleagues ${ }^{81}$ performed a retrospective study with combination of PDE5 inhibitors and VCD for early penile rehabilitation following NSRP. Patients were started on $25 \mathrm{mg}$ sildenafil 3 times a week or $5 \mathrm{mg}$ tadalafil twice a week with VCD use at least twice a day, 11 days after the RP, for 3 months. They found that $56 \%$ of patients on the PDE5 inhibitors and VCD rehabilitation program obtained erections sufficient for sexual intercourse with the use of PDE5 inhibitors before intercourse. Patients on sildenafil rehabilitation reported higher success rates than the patients on tadalafil $(78 \%$ v. $64 \%)$. The design of the study was questioned and the follow-up was very short.

Nandipati and coauthors ${ }^{48}$ conducted a prospective study with 22 patients who underwent bilateral NSRP to evaluated the role of intracavernosal alprostadil combined with sildenafil in stimulating early recovery of spontaneous erections. They showed that early intracavernosal injections facilitated early sexual intercourse, patient satisfaction and, potentially, earlier return of natural erections. Early combination therapy with sildenafil allowed a lower dose of intracavernous injections, minimizing penile discomfort. Prospective, randomized trials are needed to confirm the safety and efficacy of combination regimens.

Some key human studies on postprostatectomy penile rehabilitation are summarized in Table 3.

\section{Conclusion}

Evolving data from human volunteer studies and animal models support the basic pathophysiological effects of prostate cancer surgery-induced ED as being largely a consequence of increased cavernosal smooth muscle atrophy and fibrosis. Although few preventative strategies have been identified as feasible, clear evidence supporting the importance of an experienced surgeon able to preserve the cavernous nerves, limit the injury from cautery and minimize neural traction in improved rates of erection preservation. Additionally, evidence showing reduced intrapenile fibrosis, smooth muscle loss and improved erectile functioning among patients exposed to intracavernous 
Table 3. Human studies on postprostatectomy penile rehabilitation

\begin{tabular}{|c|c|c|c|c|}
\hline Treatment; study & Design & $\begin{array}{l}\text { No. of } \\
\text { patients }\end{array}$ & Agents & Results \\
\hline \multicolumn{5}{|l|}{ PDE5 inhibitor } \\
\hline Schwartz et al. ${ }^{68}$ & $\begin{array}{l}\text { Uncontrolled prospective } \\
\text { analysis }\end{array}$ & 40 & Sildenafil 50 v. $100 \mathrm{mg}$ & $\begin{array}{l}\text { Increased smooth muscles } \\
\text { content at higher dose }\end{array}$ \\
\hline Padma-Nathan et al. ${ }^{73}$ & $\begin{array}{l}\text { Randomized, double-blind, } \\
\text { placebo-controlled study }\end{array}$ & 76 & Nightly sildenafil v. placebo & $\begin{array}{l}\text { Increased spontaneous normal } \\
\text { erections }\end{array}$ \\
\hline Montorsi et al. ${ }^{76}$ & $\begin{array}{l}\text { Randomized, placebo- } \\
\text { controlled, double-blind, } \\
\text { multicentre study }\end{array}$ & 628 & $\begin{array}{l}\text { Vardenafil administered } \\
\text { either nightly or on- } \\
\text { demand v. placebo }\end{array}$ & $\begin{array}{l}\text { As-needed vardenafil showed } \\
\text { greater efficacy than placebo } \\
\text { (45\% v. } 24 \% \text { SEP3) }\end{array}$ \\
\hline Zumbe et al. $^{75}$ & $\begin{array}{l}\text { Placebo-controlled, } \\
\text { double-blind, multicentre } \\
\text { parallel-group study }\end{array}$ & 236 & $\begin{array}{l}\text { Once-daily v. on-demand } \\
\text { vardenafil }\end{array}$ & No difference \\
\hline \multicolumn{5}{|l|}{ ICSI } \\
\hline Montorsi et al. ${ }^{35}$ & $\begin{array}{l}\text { Prospective, randomized } \\
\text { trial }\end{array}$ & 30 & $\begin{array}{l}\text { PGE1 3/week v. no } \\
\text { treatment }\end{array}$ & $\begin{array}{l}\text { Increased spontaneous } \\
\text { erection }\end{array}$ \\
\hline Gontero et al. ${ }^{47}$ & $\begin{array}{l}\text { Randomized, prospective } \\
\text { study }\end{array}$ & 73 & $\begin{array}{l}\text { Optimal time for } \\
\text { intracavernous PGE1 } \\
\text { rehabilitation ( } 20 \text { mg PGE1) }\end{array}$ & $\begin{array}{l}\text { Increased erectile response } \\
\text { when in early rehabilitation }\end{array}$ \\
\hline Mulhall et al. ${ }^{46}$ & $\begin{array}{l}\text { Prospective, } \\
\text { nonrandomized study }\end{array}$ & 132 & $\begin{array}{l}\text { Trimix or bimix } 3 / \mathrm{wk} v \text {. no } \\
\text { treatment or as needed }\end{array}$ & $\begin{array}{l}\text { Increased \% of patients having } \\
\text { intercourse, erectile rigidity, } \\
\text { IIEF-EF, \% of patients with } \\
\text { normal erectile function, time } \\
\text { to become a sildenafil } \\
\text { responder }\end{array}$ \\
\hline \multicolumn{5}{|l|}{ Intraurethral prostaglandin } \\
\hline McCullough $^{55}$ & $\begin{array}{l}\text { Prospective, randomized } \\
\text { comparative penile } \\
\text { rehabilitation trial }\end{array}$ & 22 & $\begin{array}{l}\text { Nightly alprostadil v. } \\
\text { sildenafil }\end{array}$ & $\begin{array}{l}\text { Increased penile and glanular } \\
\text { oxygenation }\end{array}$ \\
\hline Raina et al. ${ }^{56}$ & $\begin{array}{l}\text { Prospective, } \\
\text { nonrandomized study }\end{array}$ & 91 & $\begin{array}{l}\text { Early intraurethral } \\
\text { alprostadil v. as-needed } \\
\text { oral PDE5 }\end{array}$ & $\begin{array}{l}\text { MUSE safe and tolerable, } \\
\text { decreased recovery time to } \\
\text { regain erectile function }\end{array}$ \\
\hline \multicolumn{5}{|l|}{ VCD } \\
\hline Huber et al. ${ }^{82}$ & $\begin{array}{l}\text { Randomized, prospective } \\
\text { study }\end{array}$ & 65 & VCD 4/wk v. < 4/wk & Increased penile length \\
\hline Raina et al. ${ }^{60}$ & $\begin{array}{l}\text { Prospective, randomized } \\
\text { study }\end{array}$ & 109 & $\begin{array}{l}\text { Daily VCD x } 9 \text { mo v. } \\
\text { observation }\end{array}$ & $\begin{array}{l}\text { Increased early sexual activity, } \\
\text { earlier return of erectile } \\
\text { function }\end{array}$ \\
\hline Köhler et al. ${ }^{59}$ & $\begin{array}{l}\text { Prospective, randomized } \\
\text { pilot study }\end{array}$ & 28 & $\begin{array}{l}\text { Early VCD protocol v. no } \\
\text { treatment }\end{array}$ & $\begin{array}{l}\text { Increased early sexual function, } \\
\text { preserved penile length }\end{array}$ \\
\hline \multicolumn{5}{|l|}{ Combination } \\
\hline McMahon et al. ${ }^{83}$ & $\begin{array}{l}\text { Prospective, } \\
\text { nonrandomized study }\end{array}$ & 93 & $\begin{array}{l}\text { Sildenafil alone or in } \\
\text { combination with } \\
\text { intracavernosal alprostadil }\end{array}$ & $\begin{array}{l}\text { Increased ablility to have } \\
\text { sexual intercourse, frequency } \\
\text { of penetration, ability to } \\
\text { maintain erection }\end{array}$ \\
\hline Nehra et al. ${ }^{84}$ & $\begin{array}{l}\text { Prospective, } \\
\text { nonrandomized study }\end{array}$ & 28 & $\begin{array}{l}\text { Sildenafil + intraurethral } \\
\text { PGE1 in nonresponders to } \\
\text { each monotherapy }\end{array}$ & $\begin{array}{l}\text { Increased ability to have sexual } \\
\text { intercourse }\end{array}$ \\
\hline Yassin and Saad ${ }^{81}$ & Retrospective analysis & 244 & Sildenafil or tadalafil + VCD & $\begin{array}{l}\text { Increased satisfactory erection, } \\
\text { no control group }\end{array}$ \\
\hline Nandipati et al. ${ }^{48}$ & Prospective study & 22 & $\begin{array}{l}\text { PGE1 or Trimix 2-3/wk + } \\
\text { sildenafil daily }\end{array}$ & $\begin{array}{l}\text { Facilitated early sexual } \\
\text { intercourse, increased patient } \\
\text { satisfaction, earlier return of } \\
\text { natural erections, no control } \\
\text { group }\end{array}$ \\
\hline
\end{tabular}


vasoactive injections and/or PDE5 inhibitors is supported by the bulk of the data in clinical and animal reports. The decision on whether to initiate a rehabilitation program on an individual patient should be based on patients' goals and a complete understanding of the strengths and weaknesses of the existing scientific data.

Identification of an optimal dose, route, timing and agent to enhance post-RP erectile functioning will require further study.

From the Division of Urology, Department of Surgery, University of Western Ontario, London, Ont.

This article has been peer reviewed.

Competing interests: None declared.

\section{References}

1. Meuleman EJ, Mulders PF. Erectile function after radical prostatectomy: a review [discussion 101-2]. Eur Urol 2003:43:95-101.

2. Calabrese DA. Prostate cancer in older men. Urol Nurs 2004; 24: 258-64.

3. Nakamura K, Kasraeian A, Anai S, et al. Positive surgical margins at radical prostatectomy: importance of intraoperative bladder neck frozen sections. Int Braz J Urol 2007; 33:746-51.

4. Walsh PC, Donker PJ. Impotence following radical prostatectomy: insight into etiology and prevention. J Urol 1982;128:492-7.

5. Albersen $M$, Joniau $S$, Claes $H$, et al. Preclinical evidence for the benefits of penile rehabilitation therapy following nerve sparing radical prostatectomy. Adv Urol 2008; 594868.

6. Chuang $M S, O^{\prime}$ Connor $R C$, Laven $B A$, et al. Early release of the neurovascular bundles and optical loupe magnification lead to improved and earlier return of potency following radical retropubic prostatectomy. J Urol 2005;173:537-9.

7. Masterson TA, Serio AM, Mulhall JP, et al. Modified technique for neurovascular bundle preservation during radical prostatectomy: association between technique and recovery of erectile function. BJU Int 2008;101:1217-22.

8. Nandipati KC, Raina R, Agarwal A, et al. Erectile dysfunction following radical retropubic prostatectomy: epidemiology, pathophysiology and pharmacological management. Drugs Aging 2006;23:101-17.

9. Mulhall JP, Morgentaler A. Penile rehabilitation should become the norm for radical prostatectomy patients. J Sex Med 2007;4:538-43.

10. Penson D, Moul J, Gandhi S, et al. Use of prostate-specific antigen in the follow-up of patients with localized prostate cancer: results of a nationwide survey of urologists. Urology 2006;68:80-4.

11. Kendirci $M$, Tanriverdi 0 , Trost $L$, et al. Management of sildenafil treatment failures. Curr Opin Urol 2006;16:449-59.

12. McCullough AR. Prevention and management of erectile dysfunction following radical prostatectomy. Urol Clin North Am 2001;28:613-27.

13. Raina R, Lakin MM, Agarwal A, et al. Efficacy and factors associated with successful outcome of sildenafil citrate use for erectile dysfunction after radical prostatectomy. Urology 2004;63:960-6.

14. Montorsi F, Briganti A, Salonia A, et al. Current and future strategies for preventing and managing erectile dysfunction following radical prostatectomy. Eur Urol 2004;45:123-33.

15. Burnett AL. Rationale for cavernous nerve restorative therapy to preserve erectile function after radical prostatectomy: results from CaPSURE. J Urol 2004;171:703-8.

16. Kury P, Stoll G, Muller HW. Molecular mechanisms of cellular interactions in peripheral nerve regeneration. Curr Opin Neurol 2001;14:635-9.

17. User HM, Hairston JH, Zelner DJ, et al. Penile weight and cell subtype specific changes in a postradical prostatectomy model of erectile dysfunction. J Urol 2003;169:1175-9.

18. Carrier $S$, Zvara P, Nunes L, et al. Regeneration of nitric oxide synthase-containing nerves after cavernous nerve neurotomy in the rat. J Urol 1995;153:1722-7.

19. Bannowsky A, Schulze $\mathrm{H}$, van der Horst $\mathrm{C}$, et al. Nocturnal tumescence: a parameter for postoperative erectile integrity after nerve sparing radical prostatectomy. J Urol 2006; $175: 2214-7$.

20. Kaul $S$, Bhandari A, Hemal A, et al. Robotic radical prostatectomy with preservation of the prostatic fascia: a feasibility study. Urology 2005;66:1261-5.

21. McCullough AR. Rehabilitation of erectile function following radical prostatectomy. Asian $J$ Androl 2008:10:61-74.

22. Gontero P, Kirby R. Early rehabilitation of erectile function after nerve-sparing radical prostatectomy: What is the evidence? BJU Int 2004;93:916-8.

23. Mulhall JP, Slovick R, Hotaling J, et al. Erectile dysfunction after radical prostatectomy: hemodynamic profiles and their correlation with the recovery of erectile function. J Urol 2002;167:1371-5.

24. Mulhall JP, Graydon RJ. The hemodynamics of erectile dysfunction following nerve-sparing radical retropubic prostatectomy. Int I Impot Res 1996;8:91-4.

25. Wang R. Penile rehabilitation after radical prostatectomy: Where do we stand and where are we going? I Sex Med 2007;4:1085-97.

26. Podlasek CA, Gonzalez CM, Zelner DJ, et al. Analysis of NOS isoform changes in a post radical prostatectomy model of erectile dysfunction. Int I Impot Res 2001;13 (Suppl 5):S1-15.

27. McVary KT. Alfuzosin for symptomatic benign prostatic hyperplasia: long-term experience. J Urol 2006;175:35-42.

28. Moreland RB, Traish A, MCMillin MA, et al. PGEl suppresses the induction of collagen synthesis by transforming growth factor-beta 1 in human corpus cavernosum smooth muscle. J Urol 1995;153:826-34.

29. Daley JT, Watkins MT, Brown ML, et al. Prostanoid production in rabbit corpus cavernosum. II. Inhibition by oxidative stress. J Urol 1996;156:1169-73.

30. Dall'era JE, Mills JN, Koul HK, et al. Penile rehabilitation after radical prostatectomy: Important therapy or wishful thinking? Rev Urol 2006;8:209-15.

31. Leungwattanakii S, Bivalacqua TJ, Usta MF, et al. Cavernous neurotomy causes hypoxia and fibrosis in rat corpus cavernosum. J Androl 2003;24:239-45.

32. Saenz de Tejada I, Moroukian P, Tessier J, et al. Trabecular smooth muscle modulates the capacitor function of the penis. Studies on a rabbit model. Am J Physiol 1991; 260:H1590-5.

33. Mulhall JP. Penile length changes after radical prostatectomy. BJU Int 2005;96:472-4.

34. Gontero P, Galzerano M, Bartoletti R, et al. New insights into the pathogenesis of penile shortening after radical prostatectomy and the role of postoperative sexual function. J Urol 2007; 178:602-7.

35. Montorsi F, Guazzoni G, Strambi LF, et al. Recovery of spontaneous erectile function after nerve-sparing radical retropubic prostatectomy with and without early intracavernous injections of alprostadil: results of a prospective, randomized trial. J Urol 1997;158:1408-10.

36. Goldstein AM, Meehan JP, Zakhary R, et al. New observations on microarchitecture of corpora cavernosa in man and possible relationship to mechanism of erection. Urology 1982;20:259-66.

37. Iacono F, Giannella R, Somma P, et al. Histological alterations in cavernous tissue after radical prostatectomy. J Urol 2005;173:1673-6.

38. Nehra A, Azadzoi KM, Moreland RB, et al. Cavernosal expandability is an erectile tissue mechanical property which predicts trabecular histology in an animal model of vasculogenic erectile dysfunction. J Urol 1998;159:2229-36.

39. Ruiz Rubio JL, Hernandez M, Rivera de los Arcos L, et al. Mechanisms of prostaglandin E1-induced relaxation in penile resistance arteries. J Urol 2004;171:968-73.

40. Brock $G$, Tu LM, Linet 01 . Return of spontaneous erection during long-term intracavernosal alprostadil (Caveriect) treatment. Urology 2001;57:536-41.

41. Dennis RL, McDougal WS. Pharmacological treatment of erectile dysfunction after radical prostatectomy. J Urol 1988;139:775-6.

42. Zippe $C D$, Pahlajani $G$. Penile rehabilitation following radical prostatectomy: role of early intervention and chronic therapy. [viii.]. Urol Clin North Am 2007;34:601-18.

43. Raina R, Lakin MM, Thukral $M$, et al. Long-term efficacy and compliance of intracor- 
poreal (IC) injection for erectile dysfunction following radical prostatectomy: SHIM (IIEF5) analysis. Int J Impot Res 2003;15:318-22.

44. Lakin MM, Montague DK, VanderBrug Medendorp S, et al. Intracavernous injection therapy: analysis of results and complications. J Urol 1990;143:1138-41.

45. Kava BR. Advances in the management of post-radical prostatectomy erectile dysfunction: treatment strategies when PDE-5 inhibitors don't work. Rev Urol 2005; 7(Suppl 2): S39-50.

46. Mulhall J, Land S, Parker $M$, et al. The use of an erectogenic pharmacotherapy regimen following radical prostatectomy improves recovery of spontaneous erectile function. [discussion 540-2]. J Sex Med 2005;2:532-40.

47. Gontero $P$, Fontana $F$, Bagnasacco $A$, et al. Is there an optimal time for intracavernous prostaglandin $\mathrm{El}$ rehabilitation following nonnerve sparing radical prostatectomy? Results from a hemodynamic prospective study. I Urol 2003;169:2166-9.

48. Nandipati K, Raina R, Agarwal A, et al. Early combination therapy: intracavernosal injections and sildenafil following radical prostatectomy increases sexual activity and the return of natural erections. Int I Impot Res 2006;18:446-51.

49. Bechara $\mathrm{A}$, Casabe $\mathrm{A}$, Cheliz $\mathrm{G}$, et al. Prostaglandin El versus mixture of prostaglandin $\mathrm{El}$, papaverine and phentolamine in non-responders to high papaverine plus phentolamine doses. J Urol 1996;155:913-4.

50. Baniel J, Israilov S, Segenreich E, et al. Comparative evaluation of treatments for erectile dysfunction in patients with prostate cancer after radical retropubic prostatectomy. BJU Int 2001;88:58-62.

51. Padmanaban P, McCullough AR. The effect of prostaglandin E-1 (PGE-1) urethral suppository (MUSE ${ }^{\mathrm{TM}}$ ) and injections on corporal oxygen saturation (S+O2) in men with erectile dysfunction (ED) [abstract]. American Society of Andrology Meeting 2006, Apr. 8-11, Chicago. J Androl 2006;27.

52. Porst H. Transurethral alprostadil with MUSE (Medicated Urethral System for Erection) v. intracavernous alprostadil - a comparative study in 103 patients with erectile dysfunction. Int I Impot Res 1997;9:187-92.

53. Lepor H, McCullough A. Penile rehabilitation post-prostatectomy: Is there a role for MUSE? Rev Urol 2008;10:1-5.

54. Costabile RA, Spevak M, Fishman IJ, et al. Efficacy and safety of transurethral alprostadil in patients with erectile dysfunction following radical prostatectomy. J Urol 1998; 160 : 1325-8.

55. McCullough A. The effect of low dose intraurethral alprostadil (MUSE®) on corporal oxygenation after nerve sparing radical prostatectomy. [Abstract 77]. J Sex Med 2007; 4(suppl 1):89.

56. Raina R, Pahlajani $G$, Agarwal A, et al. The early use of transurethral alprostadil after radical prostatectomy potentially facilitates an earlier return of erectile function and successful sexual activity. BJU Int 2007;100:1317-21.

57. Sidi AA, Becher EF, Zhang $G$, et al. Patient acceptance of and satisfaction with an external negative pressure device for impotence. J Urol 1990;144:1154-6.

58. Bosshardt RJ, Farwerk R, Sikora R, et al. Objective measurement of the effectiveness, therapeutic success and dynamic mechanisms of the vacuum device. Br J Urol 1995; $75: 786-91$

59. Kohler TS, Pedro R, Hendlin K, et al. A pilot study on the early use of the vacuum erection device after radical retropubic prostatectomy. BJU Int 2007;100:858-62.

60. Raina R, Agarwal A, Ausmundson $S$, et al. Early use of vacuum constriction device following radical prostatectomy facilitates early sexual activity and potentially earlier return of erectile function. Int I Impot Res 2006;18:77-81.

61. Lue TF. Erectile dysfunction. N Engl J Med 2000;342:1802-13.

62. De Young LX, Domes T, Lim K, et al. Endothelial rehabilitation: the impact of chronic PDE5 inhibitors on erectile function and protein alterations in cavernous tissue of diabetic rats. Eur Urol 2008:54:213-20.

63. Ahn GJ, Sohn YS, Kang KK, et al. The effect of PDE5 inhibition on the erectile function in streptozotocin-induced diabetic rats. Int I Impot Res 2005;17:134-41.

64. Ferrini MG, Kovanecz I, Nolazco $G$, et al. Effects of long-term vardenafil treatment on the development of fibrotic plaques in a rat model of Peyronie's disease. BJU Int
2006;:97:625-33.

65. Ferrini MG, Davila HH, Kovanecz I, et al. Vardenafil prevents fibrosis and loss of corporal smooth muscle that occurs after bilateral cavernosal nerve resection in the rat. Urology 2006;68:429-35.

66. Vignozzi L, Filippi S, Morelli A, et al. Effect of chronic tadalafil administration on penile hypoxia induced by cavernous neurotomy in the rat. J Sex Med 2006;3:419-31.

67. Kovanecz I, Rambhatla A, Ferrini M, et al. Long-term continuous sildenafil treatment ameliorates corporal veno-occlusive dysfunction (CVOD) induced by cavernosal nerve resection in rats. Int I Impot Res 2008;20:202-12.

68. Schwartz EJ, Wong P, Graydon RJ. Sildenafil preserves intracorporeal smooth muscle after radical retropubic prostatectomy. J Urol 2004;171:771-4.

69. McCullough AR, Levine LA, Padma-Nathan H. Return of nocturnal erections and erectile function after bilateral nerve-sparing radical prostatectomy in men treated nightly with sildenafil citrate: subanalysis of a longitudinal randomized double-blind placebocontrolled trial. J Sex Med 2008;5:476-84.

70. Montorsi F, Maga T, Strambi LF, et al. Sildenafil taken at bedtime significantly increases nocturnal erections: results of a placebo-controlled study. Urology 2000;56:906-11.

71. Bannowsky A, Schulze H, van der Horst C, et al. Recovery of erectile function after nerve-sparing radical prostatectomy: improvement with nightly low-dose sildenafil. BJU Int 2008;101:1279-83.

72. Padma-Nathan HMA, Guiliano F, Toler SMWC, et al. Postoperative nightly administration of sildenafil citrate significantly improves the return of normal spontaneous erectile function after bilateral nerve-sparing radical prostatectomy. [Abstract 1402]. J Urol 2003;169(suppl):375.

73. Padma-Nathan H, McCullough AR, Levine LA, et al. Randomized, double-blind, placebo-controlled study of postoperative nightly sildenafil citrate for the prevention of erectile dysfunction after bilateral nerve-sparing radical prostatectomy. Int I Impot Res 2008;20:479-86.

74. Briganti A, Salonia A, Gallina A, et al. Management of erectile dysfunction after radical prostatectomy in 2007. World J Urol 2007;25:143-8.

75. Zumbe J, Porst H, Sommer F, et al. Comparable efficacy of once-daily versus on-demand vardenafil in men with mild-to-moderate erectile dysfunction: findings of the RESTORE study. Eur Urol 2008;54:204-10.

76. Montorsi F, Brock G, Lee J, et al. Effect of nightly versus on-demand vardenafil on recovery of erectile function in men following bilateral nerve-sparing radical prostatectomy. Eur Urol 2008;54:924-31.

77. Zippe CD, Jhaveri FM, Klein EA, et al. Role of Viagra after radical prostatectomy. Urology 2000;55:241-5.

78. Raina R, Lakin MM, Agarwal A, et al. Long-term effect of sildenafil citrate on erectile dysfunction after radical prostatectomy: 3-year follow-up. Urology 2003;62:110-5.

79. Feng MI, Huang S, Kaptein J, et al. Effect of sildenafil citrate on post-radical prostatectomy erectile dysfunction. J Urol 2000;164:1935-8.

80. Reece C, Kumar R, Nienow D, et al. Extending the rationale of combination therapy to unresponsive erectile dysfunction. Rev Urol 2007:9:197-206.

81. Yassin AAHA, Saad F. Favorable effects of early "penile rehabilitation" following nerve sparing radical prostatectomy. J Sex Med 2006;3(suppl 5):407.

82. Huber N WC, Babaian R, Madsen L, et al. Recovering penile length and erectile function following radical prostatectomy. [Abstract 60]. J Sex Med 2006;3(suppl 1):32.

83. McMahon CG, Samali R, Johnson H. Treatment of intracorporeal injection nonresponse with sildenafil alone or in combination with triple agent intracorporeal injection therapy. [discussion 1997-8]. J Urol 1999;162:1992-7.

84. Nehra A, Blute ML, Barrett DM, et al. Rationale for combination therapy of intraurethral prostaglandin $E(1)$ and sildenafil in the salvage of erectile dysfunction patients desiring noninvasive therapy. Int I Impot Res 2002;14(Suppl 1):S38-42.

Correspondence: Dr. Gerald B. Brock, Division of Urology, University of Western Ontario, London 0N N6A 4V2; gebrock@sympatico.ca 